\title{
Evidence-informed policy and practice: The role and potential of civil society
}

\begin{tabular}{|c|c|}
\hline $\begin{array}{l}\text { Authors: } \\
\text { Mine Pabari } \\
\text { Matodzi M. A } \\
\text { Emmanuel Da } \\
\text { Dede Bedu-Ac } \\
\text { lan Goldman }\end{array}$ & $\begin{array}{l}\text { (D) } \\
\text { misi }^{1} \text { (D) } \\
\text { vid-Gnahoui }{ }^{2} \text { (I) } \\
\text { ddo }{ }^{3} \text { (D) } \\
\text { (D) }\end{array}$ \\
\hline $\begin{array}{l}\text { Affiliations: } \\
{ }^{1} \text { CLEAR Anglo } \\
\text { (CLEAR AA), F } \\
\text { Commerce, Lc } \\
\text { Management } \\
\text { of the Witwat } \\
\text { Johannesburg }\end{array}$ & $\begin{array}{l}\text { aculty of } \\
\text { Un and } \\
\text { University } \\
\text { ersrand, } \\
\text { South Africa }\end{array}$ \\
\hline $\begin{array}{l}{ }^{2} \text { Faculty of Hu } \\
\text { Sciences, Unis } \\
\text { Abomey-Cala } \\
\text { Benin }\end{array}$ & $\begin{array}{l}\text { man and Social } \\
\text { ersity of } \\
\text { ii, Cotonou, }\end{array}$ \\
\hline $\begin{array}{l}{ }^{3} \text { Ghana Monit } \\
\text { Evaluation For } \\
\text { Accra, Ghana }\end{array}$ & $\begin{array}{l}\text { oring and } \\
\text { rum (GMEF), }\end{array}$ \\
\hline $\begin{array}{l}\text { Correspondin } \\
\text { Mine Pabari, } \\
\text { mine.pabari@ } \\
\text { co.ke }\end{array}$ & $\begin{array}{l}\text { g author: } \\
\text { athariadvisory. }\end{array}$ \\
\hline $\begin{array}{l}\text { Dates: } \\
\text { Received: } 19 \\
\text { Accepted: } 04 \\
\text { Published: } 30\end{array}$ & $\begin{array}{l}\text { Jeb. } 2020 \\
\text { June } 2020 \\
\text { July } 2020\end{array}$ \\
\hline $\begin{array}{l}\text { How to cite th } \\
\text { Pabari, M., An } \\
\text { David-Gnahou } \\
\text { Addo, D. \& Go } \\
\text { 'Evidence-info } \\
\text { and practice: } \\
\text { potential of ci } \\
\text { African Evaluc } \\
8(1) \text {, a470. htt } \\
\text { org/10.4102/ }\end{array}$ & $\begin{array}{l}\text { is article: } \\
\text { nisi, M.M., } \\
\text { ii, E., Bedu- } \\
\text { Idman, I., 2020, } \\
\text { rmed policy } \\
\text { The role and } \\
\text { vil society', } \\
\text { ttion Journal } \\
\text { ps://doi. } \\
\text { aej.v8i1.470 }\end{array}$ \\
\hline $\begin{array}{l}\text { Copyright: } \\
\text { (C) 2020. The A } \\
\text { Licensee: AOS } \\
\text { is licensed unc } \\
\text { Creative Comr } \\
\text { Attribution Lic }\end{array}$ & $\begin{array}{l}\text { Authors. } \\
\text { IS. This work } \\
\text { der the } \\
\text { mons } \\
\text { ense. }\end{array}$ \\
\hline Read online: & \\
\hline 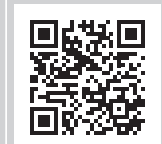 & $\begin{array}{l}\text { Scan this QR } \\
\text { code with your } \\
\text { smart phone or } \\
\text { mobile device } \\
\text { to read online. }\end{array}$ \\
\hline
\end{tabular}

Background: This article is based on a case study research on evidence use in Africa, drawing from four cases to focus on the role of civil society in evidence use. The countries included Benin, South Africa, Kenya and Ghana and sectors included agriculture, violence against women and children, sanitation and wildlife.

Objective: The objective of this article is to discuss emerging lessons from the experiences of engaging civil society in evidence-informed policy-making and practice in different countries and sectors.

Method: This research examined processes enabling and hindering evidence use using a demand (policy) rather than supply (research) perspective. It was guided by an analytical framework using a behaviour change approach to understand the evidence journey. It used a case study approach applying qualitative methods.

Results: The cases show that civil society organisations (CSOs) can make a valuable contribution towards evidence-informed policy and practice through a variety of different roles. They also demonstrate the implications of participation levels and relationship types between government and CSOs as well as within CSOs. The cases equally demonstrate the significance of evidence-informed engagement processes.

Conclusion: Deliberate efforts need to be made to maximise the value and potential of CSOs in evidence-based policy and practice. This includes establishing relationships and trust through dialogue, supported by strong facilitation, knowledge brokering and well-defined guidelines and incentives. This requires ensuring that the right capabilities are in place for the different actors to engage effectively.

Keywords: Civil society; Evidence use; Evidence-informed policymaking; Sustainable development; Citizen engagement.

\section{Introduction}

\section{Background}

This article draws on a case study research carried out for the project, 'Evidence in practice: Documenting and sharing lessons of evidence-informed policy making and implementation in Africa', supported by the Hewlett Foundation. The project focused on evidence use, which is usually challenging and complex, even in situations where there is adequate access to highquality data and information (Cairney 2016; Parkhurst 2017). The research examined the processes supporting or inhibiting evidence use in a variety of different African contexts and development sectors. ${ }^{1}$ Lessons that emerged from this research are being shared through a published book, ${ }^{2}$ policy briefs and short documentaries.

In this article, we take a closer look at the role of civil society in engaging in development policy and practice and the significance of evidence in doing so. We argue that the use of evidence adds value to civil society's efforts to influence and support policy and practice, and that civil society can play a valuable role in supporting evidence use by governments. We also explore ways in which civil society may be able to better use, promote and support evidence use and the role of policy-makers in enabling this.

1.The case study research took place in five countries (Benin, Ghana, Kenya, South Africa and Uganda) plus the Economic Community of West African States (ECOWAS)

2.Entitled, Using Evidence for Policy and Practice - Lessons from Africa, by lan Goldman and Mine Pabari (eds.), published by Routledge (London), on 18 June 2020 


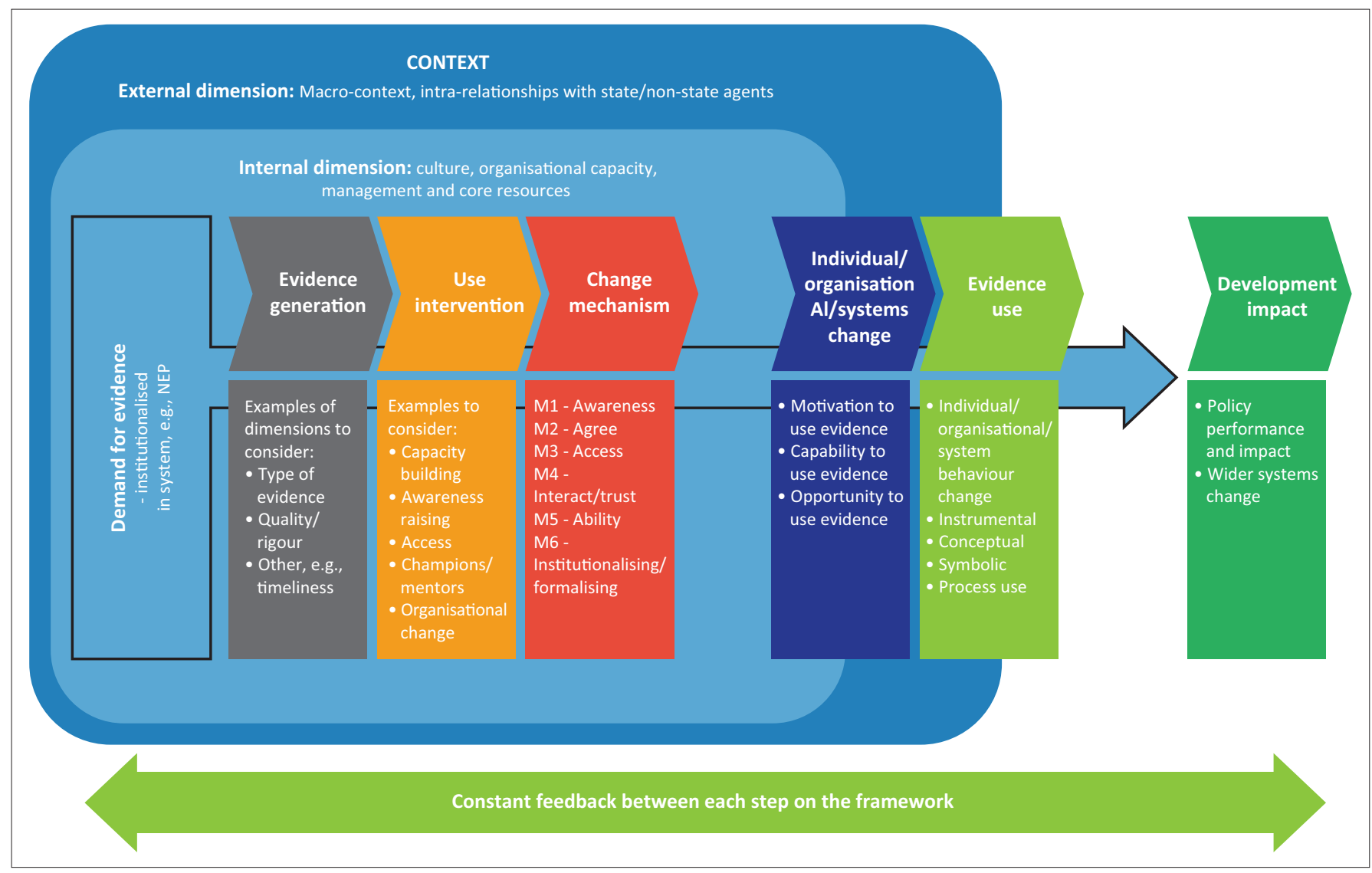

Source: Langer, L., Goldman, I. \& Pabari, M., 2020, Analytical framework used to guide case study research. In Using evidence for policy and practice - Lessons from Africa, Routledge, Taylor \& Francis Group, New York, NY.

FIGURE 1: Analytical framework used to guide the case study research.

We discuss the experiences from four of the case studies from the research, which are:

- the development of the agricultural policy in Benin and the way in which a more inclusive approach involving civil society strengthened the use of evidence and, ultimately, the policy process

- the role of socially led processes and dialogue in enabling civil society engagement and evidence use in countering violence against women and children (VAWC) in South Africa

- the significance of civil society evidence and engagement during the review of the Kenyan Wildlife Conservation and Management Act (WCMA 2013)

- the promotion of evidence use by civil society to improve the performance of the sanitation sector in Ghana.

\section{Research methods and design}

The case study research was guided by an analytical framework (Figure 1) that combines two different frameworks: (1) the Science of Using Science's framework that looks at evidence interventions and outcomes from a behaviour change perspective (Langer et al. 2016) and the Context Matters framework that serves as a tool to better understand contextual factors affecting the use of evidence (Weyrauch, Echt \& Suliman 2016). The framework approaches evidence use from a policy-makers' perspective (i.e. from a demand rather than supply perspective). The framework takes into account contextual influencers and breaks down an evidence journey into the ways in which evidence is generated, the interventions taken in order to ensure evidence use, the change mechanisms that arise as a result and the relationships between the evidence journey and the immediate and wider outcomes that emerge (Goldman \& Pabari 2020). Data for the case studies were collected through literature reviews, interviews with key stakeholders and workshops or focus groups. Participant observation ${ }^{3}$ took place in two of the cases ${ }^{4}$ where the researchers had previously been involved with the case.

\section{Civil society, policy and evidence use: An overview}

\section{An overview}

The literature on civil society is extensive, with a diversity of definitions and debates around what civil society is and is not, the functions it plays and its relationship with the state (Edwards 2011; Obadare 2014). For the purposes of this article, we maintain our focus on civil society organisations (CSOs), recognising that they cover a wide range in terms of size and mandates from informal grassroots organisations to

3.A fairly well-established data collection method, particularly for ethnographic
studies. Advantages and limitations of the method, including the potential of studies. Advantages and limitations of the method,
researcher bias, are well described by Kawulich (2005)

4.These are violence against women and children in South Africa and the development of the agricultural policy in Benin. 
the formally registered development non-governmental organisations (NGOs) and non-profits.

According to CIVICUS, ${ }^{5}$ civic space is key to the ability of CSOs to effectively engage and is consisted of three basic elements: freedom of association, peaceful assembly and expression. These freedoms enable civil society to influence agendas by engaging in debate and discussion and to advocate, provide and monitor service delivery, amongst other critical functions.

Increasingly, concerns are raised regarding the shrinking civic space in Africa which has implications for their use of evidence. The 2018 African Governance Index report noted that progress in participation and human rights has been undermined by shrinking civil society space (Mo Ibrahim Foundation 2018). These spaces are restricted in a number of ways, for example, through restrictive legislation, policies and procedures, limiting access to fora and online platforms or inadequately protecting the safety of individuals (Green 2019; Kode 2018).

\section{The importance of civil society in development policy and practice}

Civil society organisations make a significant contribution to achieve the sustainable development agenda globally. According to statistics based on development assistance committee (DAC) members reporting, between 2010 and 2017, development aid to and through CSOs alone rose from $\$ 17$ billion (bn) to $\$ 20 \mathrm{bn}$. Of the gross disbursements in 2016-2017, $48 \%$ went to social infrastructure and services (OECD 2019).

The global commitment to strengthen the partnership between government and civil society is demonstrated by the Sustainable Development Goals (SDGs), with Goal 17 focussing on partnerships and a global target to 'encourage and promote effective public, public-private and civil society partnerships, building on the experience and resourcing strategies of partnerships' (United Nations [UN] General Assembly 2015:27, 35).

\section{The role of civil society in evidence generation and use}

The research on which this article is based is guided by the definition of evidence used by Cairney (2016), who stated that 'evidence is assertion backed by information'. We include a wide range of types and sources of evidence, ranging from statistical studies to evaluations as well as descriptive and experiential evidence.

Civil society organisations have a key role to play in evidence generation, through involvement in formal processes of research, through their ability to provide the views of citizens or using evidence to provide oversight of the operation of the state. Court et al. (2006) discussed the significance of the use of evidence by CSOs, concluding that:

5.A global civil society alliance, focused on strengthening citizen action and civil society - https://monitor.civicus.org/about/aboutcivicus/. (i) $[B]$ etter outcomes stem from better policy and practice; (ii) better policy and practice occur when rigorous, systematic evidence is used; and (iii) CSOs that use evidence better will have greater policy influence and greater pro-poor impact. (p. 7)

Rainey, Wakunuma and Stahl (2017) conducted a literature review to explore the involvement of CSOs in research policy and practice and identified a number of benefits, including 'capacity building, dissemination providing local knowledge, transforming the system to become more responsive, multi-dimensional legitimacy...'. They also identified concerns and risks of engaging CSOs, many of which relate to legitimacy.

This article builds on the existing body of knowledge, exploring the use of evidence from a demand perspective rather than a supply (research-driven) perspective. The case studies here focus more on the role of CSOs in supporting and promoting the use of evidence by citizens and governments in policy dialogue processes as opposed to the roles of CSOs in generating evidence.

\section{Civil society organisations engagement in development policy and practice and the use of evidence}

\section{Functions and roles}

Table 1 suggests a mapping of the relationships between CSOs, policy and evidence use. It is based on a set of CSO roles adapted from Court et al. (2006), as well as the work of Rainey et al. (2017) and others on the role of CSOs in research.

\section{Nature and quality of engagement}

The interaction between CSOs and the state differs across all of these different roles and situations. The 'four- $\mathrm{C}$ model' presented by Najam (2000) and Public Affairs Research Institute (PARI) (2016) provides a useful framing to think through the nature of relationship between CSOs and the state. The four types of relationships suggested are:

- Cooperative - likely to exist when goals and strategies are similar.

- Confrontational - goals and strategies are at odds and actors feel threatened by one another.

- Complementary - goals are similar but strategies differ.

- Co-optive - strategies are similar but goals are divergent.

This interaction can be influenced by the nature of the relationship between policymakers and CSOs, the extent to which goals and aspirations are similar, as well as a host of other factors. The quality of engagement of CSOs can be linked to the nature of their participation, from manipulation, through token consultation, to a meaningful and powerful involvement. Arnsteins' (1969) ladder of citizen participation offers a helpful framing, identifying the following three levels that are further divided into eight 'rungs' ${ }^{6}$ :

6.It is beyond the scope of this article to describe these levels in detail. It is assumed that the titles of each rung are self-explanatory. A detailed description is available in Arnstein (1969). 
Source: Developed by authors drawing on multiple sources including Court et al. (2006), Pollard, Court and Overseas Development Institute (2005) and Rainey et al. (2017).

1. Non-participation - includes manipulation and therapy.

2. Degrees of tokenism - informing and consultation.

3. Degrees of citizen power - partnership, delegated power and citizen control.

\section{Four African cases of civil society involvement in evidence use}

\section{Inclusive approaches and evidence use in the development of the agricultural policy in Benin}

\section{Introduction}

The agriculture sector of Benin generates about $70 \%$ of employment and $30 \%$ of gross domestic product (GDP). There are an estimated 550000 smallholdings averaging 1.7 hectares, largely subsistence family farms. Civil society associations represent producers in negotiation with other actors, particularly government and development partners (DPs). The Benin case focuses on how producer unions succeeded in assuming more important roles in the agricultural sector. They shifted from a passive position where policymaking was dominated by the ministry to an active role where they are leading many important activities, including more effective evidence generation and use as well as involvement in policymaking and implementation.

\section{The role of civil society}

The main civil society organisations in the agricultural sector are the Platform of Civil Society Stakeholders in Benin (PASCiB) and the producer unions federated under the National Platform of Agricultural Farmer and Producer Organisations (PNOPPA). The Platform of Civil Society Stakeholders in Benin is a national organisation that specialises in advocacy at regional and international levels and is influential in decision-making in the agricultural sector. The National Platform of Agricultural Farmer and Producer Organisations organises services to members including procurement, market research, marketing support, facilitation of access to financing and other services to improve agricultural production (service delivery/technical inputs). ${ }^{7}$ The support of DPs has enabled PNOPPA to become a significant force in evidence generation and in the development of policies and strategies and their implementation.

\section{The role of CSOs in the evidence process}

Between the early 1970s and 2010, agricultural policies were developed by the ministry with little regard to nongovernment stakeholders. These policies were developed to meet the bureaucratic requirements of government or to align with DP agendas rather than to have a meaningful impact on the sector.

In 2008, an evaluation of agricultural sector policies over the period 1990-2008 was launched as part of the new national evaluation system (NES). The results were validated in a national workshop including CSOs.

At the same time, a revision process of the Strategic Plan for the Revival of the Agricultural Sector (PSRSA) 2006-2015 was underway, influenced by DPs (Mongbo \& Aguemon 2015). As in the past, the Ministry of Agriculture staff took the lead and established a technical committee which drew up a new version of the policy and submitted this to a validation workshop with stakeholders for endorsement. Clearly dissatisfied with the comments made at this national validation workshop, DPs expressed reservations about the content (Mongbo \& Aguemon 2015:8) which were endorsed by PNOPPA, which criticised the ministry staff for 'treating other stakeholders in the agricultural sector like their subjects'.

The National Platform of Agricultural Farmer and Producer Organisations moved on to propose a new inclusive institutional framework with civil society actors playing decisive roles (including advocacy, technical inputs and/or representation roles). Thus, the revision of the PSRSA not only introduced a formal role for non-government actors but also initiated a process of improvement of the quality of data production and use. Evidence produced by the 2009 evaluation became a significant input in developing subsequent sector policies (MPD 2016:6). This raised the profile of evaluation as a 
method of evidence generation and stimulated the demand for evidence. With the revision of the PSRSA, the demand for evidence became less for compliance and more use-oriented, responding to the needs of producers in the field, rather than demand by DPs or the ministry's planning process.

Apart from the increased availability and use of evaluation evidence, the establishment of an inclusive institutional framework created an environment where the development of public policy is no longer just the responsibility of the ministry. As noted by a respondent from Belgian Cooperation:

'[T]he empowerment of producer organisations had a huge impact. Whether it is the National Chamber of Agriculture, PASCiB or PNOPPA, these organisations have become indispensable and even take the lead on several issues'. (Male participant, 50-55 years old, Assistant Technique Cooperation Belge)

\section{What could have been done differently}

Civil society organisations are currently playing more dynamic roles related to the agricultural production system and have assumed control over evidence generation and use. Whilst government created a specific budget line for CSO support in 2017, the funds have not been made available so far. Hence, most CSO activities are still funded by DPs, reducing the sustainability of their capacity.

The state's withdrawal from the activities of production, marketing, processing and the transfer of those prerogatives to other actors in the rural sector, including producer organisations and the private sector (MDR 2000:4), is still incomplete, indicating further areas where CSO involvement can make a difference.

\section{Engagement of civil society evidence in the review of the Kenyan Wildlife Conservation and Management Act (2013)}

\section{Introduction}

Civil society is a key player in Kenya's development trajectory. A report of CSO dialogues in Kenya held in 2014 described the sector as '.. one of the most vibrant in the region, employing 350,000 persons, contributing to about $15 \%$ of GDP and operating in more than 26 sectors' (Keter 2014:1). The role of CSOs is recognised in national plans, such as the country's Vision 2030 and Medium-Term Plan (MTP-III), which recognise the importance of civil society in realising national development aspirations. However, in practice, civic space in Kenya is described as 'obstructed's by CIVICUS,' with routine violations of the freedom of peaceful assembly.

The wildlife sector in Kenya is complex, with diverse vested interests and polarised values. Civil society has been instrumental in influencing the sector since Kenya's independence in 1963 and, in particular, the different attempts to review the WCMA between 2006 and 2013. This

\footnotetext{
8. Heavily contested and undermined by power holders and vulnerable to frequent use of excessive force (definitions of ratings are available at: https://monitor.civicus. org/Ratings/).
}

9.See https://monitor.civicus.org/about/aboutcivicus/. case study sought to understand the relationships that played out between government and CSOs and how CSOs used evidence to influence the policies of the sector.

\section{The role of civil society}

As in other sectors, CSOs in the wildlife sector emerged in the 1990s, largely as a consequence of the inabilities of government to fulfil its functions and the donor community channelling much of their funding through NGOs (KameriMbote 2000). In addition to implementing projects, civil society has been instrumental in influencing wildlife governance reform. The spaces provided by government for CSO engagement have varied, ranging from partnerships to consultation and even manipulation. The ways in which CSOs have engaged in influencing the sector have been equally varied - not only amongst the different organisations involved but also with individual organisations choosing to play different roles, using different techniques and evidence in different ways at different points in time.

\section{Revising the Act}

In 2006/2007 and 2010/2012, two different attempts were made to review the Wildlife Act 1976, Cap 376. Previous attempts to revise the 1976 Act could perhaps be characterised as 'manipulative', using Arnstein's (1969) ladder of participation. For example, individuals interviewed for this case study stated that in the 2010/2012 review process, the Bill that they submitted to the Ministry of Wildlife, Environment, Water and Natural Resources (MEWNR) was altered significantly. The level of concern raised around transparency resulted in the process being abandoned, a loss of trust between government and civil society and a sense that the aspirations of both parties with regard to the sector were at odds.

In both instances, different NGOs secured funding from a DP and supported the government in gathering evidence to inform the review process. This included extensive stakeholder consultations, literature reviews and expert inputs (technical inputs). In 2013, the poaching crises had come to a head, and international pressure to address the situation was mounting as was the urgency to revise legislation to meet the requirements of the new Constitution. Together, these factors contributed to an environment where both government and civil society had a shared sense of urgency to unlock the policy processes, which, in turn, gave rise to a more cooperative environment.

The wildlife sector includes communities in remote areas that are difficult to access and communicate with. Civil society organisations played an important role in ensuring that the views of communities were represented in policy forums (representation). This was carried out in a number of different ways. Individual organisations supported community representatives to speak at relevant forums, speak on their behalf and/or use studies/assessments or experiential evidence. In addition, communities have used conservancies ${ }^{10}$

10.'A wildlife conservancy is land managed by an individual landowner, a body or corporate, group of owners or a community for purposes of wildlife conservation and other compatible land uses to better livelihoods' (https://kwcakenya.com/ conservancies/). 
to speak on their behalf. Some conservancies have come together to form institutions that represent their common interests and form linkages with communities around the conservancies and ranches (e.g. the Laikipia Wildlife Forum and the Northern Rangelands Trust).

A number of CSOs also actively lobbied around particular issues through presenting position papers/statements drawing on either experiential evidence or studies specifically carried out for this purpose (advocacy). Examples include studies carried out by the NGO, Wildlife Direct, to lobby for more stringent penalties for wildlife crime.

The review process was led by a parliamentary committee, the Departmental Committee on Environment and Natural Resources (DCENR) supported by a knowledge broker role played by the Parliamentary Research Services (PRS). The PRS received, collated and analysed written and oral proposals from stakeholders and provided the interface between the DCENR and civil society.

Following CSO engagement in the review process, (1) the Act came into force (after multiple failed attempts); (2) the Act reflected submissions made through the public participatory processes and therefore enjoyed widespread ownership, with a number of CSOs supporting its implementation (through, e.g., raising awareness amongst the wider public); and (3) the experiences of the engagement process were used in the developing and strengthening of parliamentary processes for public participation.

\section{Factors influencing the journey}

The members of parliament in the DCENR ensured that the views of the communities they represented were included during the review process. In addition, important leadership roles were played by the chairperson of DCENR and the Cabinet Secretary of MEWNR. Both individuals were highly knowledgeable about the sector, had well established relationships across both government and non-government sectors and were very clear on the importance of engaging civil society. At the same time, civil societies had established relationships amongst themselves, with well-developed agendas and evidence to back their positions. Furthermore, the existence of platforms such as the Kenya Wildlife and Conservation Association (KWCA) strengthened the collective voice of local communities. Of significance was also the knowledge broker roles played by the PRS supporting DCENR.

\section{What could have been done differently}

At the time the WCMA 2013 review process was taking place, capabilities for public participation in the country were underdeveloped. There were no guidelines or regulations in place and the DCENR had limited budgetary resources and time at their disposal. As a consequence, there were a number of shortcomings, including limitations in representation and voice. Limitations in government capabilities meant that there was a reliance on the evidence submitted by civil society participating in the process. This resulted in questions and concerns around elite capture and the robustness of the evidence that ultimately influenced the contents of the Act.

\section{The role of evidence in socially led processes and dialogue to counter violence against women and children in South Africa}

\section{Introduction}

This case explores the importance of CSOs in enabling evidence use around VAWC, even where the source of evidence was commissioned by government. It uses the Diagnostic Review (evaluation) of government's response to VAWC, commissioned in 2014 by the Department of Planning, Monitoring and Evaluation (DPME) together with the Department of Social Development (DSD) and undertaken in 2015 by KPMG. The review was demanded by the recently established Inter-Ministerial Committee headed by the Minister of Social Development. It followed the process stipulated by the South African NES, including having a multisector steering committee, peer reviewers, submission to cabinet and making the report public. The completed review and improvement plan were approved by the Cabinet in 2018. Together with other interventions, the Diagnostic Review has been influential within the VAWC sector, including shaping the National Strategic Plan for GenderBased Violence and Femicide. ${ }^{11}$

\section{Civil society organisations in violence against women and children}

South Africa has a vibrant civic movement with long history of protests against discriminatory apartheid policies, involvement in policy advocacy and service delivery. According to the Not-for-Profit Organisation (NPO) Register, as of 05 February 2016 there were 150456 organised CSOs registered across 11 sectors and 33 objectives in South Africa (DPME \& DSD 2016, 2017). More than $90 \%$ of social welfare services are provided by NGOs (Barberton et al. 2018), including VAWC services. In addition, many NGOs in VAWC work to influence and shape government policies through advocacy. As there are at least 10 departments and many different units within departments working on different aspects of VAWC, CSOs have various entry points where they interact with government (DPME \& DSD 2016). Although the sector is often characterised by conflict between NGOs and government, applying Najam 's (2000) theory of institutional strategic interest it can be argued that government-NGO relationships in the sector moves between collaboration, cooperation, confrontation and even co-option depending on the issue at hand. This oscillation in government-CSO interaction was experienced both in the process of doing the Diagnostic Review and getting it used in policy processes.

\section{The role of civil society organisations in evidence generation, use and the changes that resulted}

Civil society organisations provided technical inputs to the Diagnostic Review. During the Review, the evaluators 11.The final NSP was published in 2020 (https://justice.gov.za/vg/gbv/NSP-GBVFFINAL-DOC-04-05.pdf). 
recognised that for the study to be accepted by CSOs they had to be involved in the research process. The 2011 National Evaluation Policy Framework is not explicit about the involvement of CSOs in government evaluation processes. It specifies the roles of evaluation steering committees and technical working groups but does not mandate government to ensure the participation of CSOs in these. When planning the Review, the evaluators hosted and funded two workshops with relevant CSOs to shape the scope of the research. In addition, one of the peer reviewers of the Diagnostic Review was a well-known civil society activist. Lastly, CSOs participated in the validation workshop and the process of developing an improvement plan arising from the Diagnostic Review. Most of these interactions were collaborative and cooperative, although there were areas of confrontation around disagreements on recommendations, or unresolved anger about failures of previous government interventions. This CSO-government interaction in the process of the Diagnostic Review built CSOs' awareness of the work government was doing, and once it was completed CSOs put pressure on government to use the evidence.

Another important example of cooperation was the role of CSOs as a knowledge broker and strengthening the capabilities of other CSOs to use evidence (capacity building), for example, by offering platforms to translate the Diagnostic Review to an accessible set of messages, and co-authoring of a policy brief with government (Gould et al. 2017). In addition, CSO-led forums, such as the Violence Prevention Forum (VPF), provided spaces to foster trusting, respectful and collaborative relationships between the researchers, CSOs and government working on VAWC and to share information and knowledge (Gould 2018). This forum was instrumental in collective sense-making and generating motivation for different actors to act on the Diagnostic Review findings. Another important CSO-led multi-sectoral space was provided by Soul City through the 2016/2017 Social Lab process. From Social Lab a 'think tank' (working group) made up of the Department of Women, National Treasury and NGOs was formed to explore the gender responsiveness of government plans and budgets, which the DPME was invited to participate in because of the Diagnostic Review recommendation to address the shortfalls in VAWC funding.

On 01 August 2018, a grassroots women's movement mobilised women to march against gender-based violence (GBV) under the umbrella of a campaign entitled, 'Total Shut Down'. Nine marches were held and a memorandum with 24 demands was delivered to the President. Total Shut Down aggregated women's voices, notably their experiences with VAWC. This was a good example of a confrontational interaction between government and CSOs. However, the movement brought GBV back on the political agenda, gave impetus for government to respond and provided an opportunity for evidence to influence policy responses (advocacy).

In 2018, the National Treasury announced an additional budget allocation to provincial departments of social development for VAWC programmes. The budget was increased by R206 million in financial year 2018/2019, whilst R309m was added for the financial year 2019/2020. The increase came about because of the findings of the Diagnostic Review as well as the interventions of CSOs to strengthen the Treasury's understanding of the challenges of VAWC and the ways in which these challenges could be addressed, building on years of advocacy by different CSOs.

\section{Factors that influenced this journey}

Civil society organisations-led multi-sectoral platforms such as the VPF and Social Lab created spaces for ongoing dialogue and relationship building that enabled the use of evidence. The spaces for dialogue allowed CSOs to draw on knowledge brokering approaches to influence government policies and decisions. They also built relationships that opened information flows and encouraged cooperation between CSOs and government in ways that had not always been possible in a sector characterised by fragmentation and conflictual relations.

The case study also found that although CSOs were important in enabling evidence use, in this particular case it worked well because of the strong knowledge brokering role played by DPME and DSD. Respondents indicated that government itself widely disseminated findings of the Diagnostic Review and was willing to accept where things did not work so well. This facilitated difficult conversations about the failures to address one of the most pressing challenges that South Africa is facing.

The involvement of CSOs during the evaluation itself was an important enabler. Civil society organisations (particularly think tanks) had been involved in the conceptualisation of the study, as peer reviewers, and they also participated in the validation and the process of developing an improvement plan. Drawing technical inputs from CSOs earlier on in the Diagnostic Review enriched the arguments in the Review and ensured it addressed some of the pressing issues faced by CSOs in the sector. This contributed to ensure agreement of CSOs with the findings and recommendations of the Review. Applying Najam's (2000) theory, because the ends pursued by government and CSOs were similar (improve state response to VAWC), there were more incentives for cooperation and complementarity interactions that enabled evidence use.

The advocacy and mobilisation that happened with Total Shut Down was also an important catalyst. It created an opportunity and political pressure on government to take evidence seriously. Those interviewed in the case study strongly felt that Total Shut Down put VAWC back on the political agenda and that this gave impetus and sense of urgency to government, mostly because it happened just after the change of president of the ruling political party (and so presidential candidate) leading up to the May 2019 general elections. Thus, even where the interactions between government and CSO were confrontational, this 
served to facilitate the use of evidence as government had to respond to the problem.

\section{What could have been done differently}

Because the Evaluation Steering Committee was an existing government technical team of the Inter-Ministerial Committee (IMC), it was not possible to include CSOs in the Committee. At the time, the NES did not make CSO participation in steering committees mandatory. Departments did not have incentives to ensure that CSOs participate in the steering committee. Although other means were found for CSOs to participate in the evaluation process, their inputs could have been strengthened if they were able to participate in the formal processes of approving Terms of Reference (ToRs), shaping and approving the final evaluation report.

When the evaluation was conceptualised, it aimed to respond to a policy question from the inter-ministerial committee. Therefore, most evidence use interventions were designed to facilitate use by government. This includes presentations in department management forums, briefing ministers, presentations in government clusters of heads of departments and the Cabinet. There was no broader campaign strategy to use the Diagnostic Review to influence how different stakeholders are responding to VAWC, whether government, CSOs, DPs, etc. This is despite the evident failings of current approaches as witnessed by the numbers of women and children that are victims of violence in South Africa. This diminished the potential for the Diagnostic Review to transform how the country is responding to the problem.

\section{The contribution of civil society-generated evidence to social accountability for improved service delivery in Ghana}

\section{Introduction}

Ghana is a relatively inclusive society with high levels of civil society participation. In 2017, the Ibrahim Index of African Governance (IIAG) scores for civil society participation in Ghana stood at $94.3 \%{ }^{12}$ Over the years, this has allowed for the development of partnerships between key government ministries, departments and agencies and civil society, at both the national and subnational, district levels.

In Ghana, access to timely policy-relevant data has been a major constraint in fostering government accountability and effective service provision (Centre for Democratic Development [CDD] Ghana 2017). Government produces its own data through the work of key ministries, departments and agencies at both the national and local levels. However, access to these data particularly by social accountability actors is very limited because of both technical (government data tend not to be in user-friendly formats) and weak governance frameworks and protocols for data sharing. Civil society organisations have also produced a lot of evidence, which tends to be disputed by the public sector for perceived reasons such as limited coverage, lack of robustness and reliability.

12.See http://s.mo.ibrahim.foundation/u/2018/10/26173830/2018-IIAG-scorecard GH.pdf.

\section{The roles of civil society in evidence generation}

This partnership approach has extended to allow CSOs to manage government data. The role of an NGO, the Ghana Centre for Democratic Development (CDD-Ghana), has been particularly significant, introducing the 'I am Aware (IAA)' initiative and District League Table (DLT) projects. The Centre for Democratic Development Ghana is a nonpartisan, non-governmental, not-for-profit research and policy advocacy institute working to support and advance democracy, good governance and inclusive development in Ghana and Africa. It is reputable for collecting and analysing both citizen- and government-generated data to inform and influence policy and practice in Ghana and in other African countries. As it was founded 20 years ago, the Centre's empirical studies, national and Africa-wide Afrobarometer surveys that track citizen attitudes/opinions and values on democracy and governance, the economy, civil society and other related issues, for example, have stimulated policy discussions and nationwide debates and shifted attention to the use of evidence in government interventions and decision-making. This case focuses on two CDD-Ghana initiatives as examples of where CSOs have been key change agents in getting government to use evidence for service delivery improvements: the IAA and the DLT projects.

The IAA initiative ${ }^{13}$ is one of CDD-Ghana's flagship social accountability interventions. The initiative is a 'non-partisan citizen empowerment tool' established in 2011 to empower citizens and improve their awareness and engagement with government agencies at all levels. It collects government data on the quality and supply of public goods and services, which are disaggregated at the district level. The data are analysed and synthesised to produce free, accessible and user-friendly district performance scorecards on the provision of public goods and services in order to strengthen the demand for and supply of public accountability (technical inputs). The Centre for Democratic DevelopmentGhana works with CSO partners who have been trained to work in the regions: each region is covered by one CSO for two districts per region. These IAA district partners organise Citizens' Social Action Groups (representation) that are trained on how to analyse and interpret the IAA data and use it to demand accountability and better services from government (capacity building). Other groups include parent/teacher associations (PTAs), farmer-based groups (FBOs), women's groups and youth groups that are representative and inclusive of all zones of the participating districts. They also receive governance and accountability literacy training at the local level. The groups then go back to work with their communities to raise awareness and build capacity to foster community action on public service delivery issues (advocacy).

Working with various partners and government agencies at both national and sub-national levels, the project then disseminates district-level information focused on service delivery performance through radio, town hall meetings 13.See https://www.cddgh.org/i-am-aware-ghana-iaa/. 
and the use of short message service (SMS) text messages (Jones et al. 2019) (advocacy).

The IAA project has a data facility centre where CDD-Ghana staff members assemble, archive and disseminate government data for citizen feedback on service delivery performance through the channels mentioned above. The IAA project conducts further analysis of the service provision's institutional, accountability and governance context. These are shared locally through fact sheets and briefing reports in local languages with citizens and used for discussions with government officials in live interaction sessions on radio (advocacy).

In 2014, CDD-Ghana through the IAA project partnered with the United Nations Children's Fund (UNICEF) Ghana to design and launch the Ghana DLT. ${ }^{14}$ The United Nations Children's Fund has tried and tested this tool previously in Latin America and in the Ghanaian context in general, and the IAA initiative in particular, which seemed appropriate for advocating evidence use. The DLT aims to increase social accountability for development in order to improve responsiveness in service delivery (advocacy). It seeks to improve citizens' access to information about the state, provision and quality of basic public goods and social services in order to increase their demand for accountability. The DLT seeks to support government and the general public to be more aware of development levels across the country, track progress made, and through peer pressure, improve people's welfare in the districts by motivating district assemblies to improve services.

\section{Effectiveness of the engagement}

Overall, the IAA and DLT have made significant contributions to the use of evidence by both civil society and government entities, particularly at local government level.

The initiatives strengthened the capacity of civil society to utilise evidence in their advocacy efforts as well as government's ability to use evidence in monitoring and making decisions around service delivery.

There are a number of different examples emerging of successful district-level advocacy efforts by civil society as a result of the use of evidence generated by the DLT. The annual national launch of the DLT is an important opportunity for dissemination and debate in order to gain acceptance and ownership amongst districts and ministries about the evidence and how it is generated and the policy implications. These conversations influence planning and resource allocation at the district and national levels. The district-level engagements also examine the indicators for capacity development at local level, which shapes the Local Government Staff Performance Contracts. It also feeds into the national level discussions around resource allocation for districts.

14.See https://www.cddgh.org/district-league-table-dit/.

\section{What could have been done differently}

Some key lessons are that the data ecosystem and governance infrastructure in Ghana need to be strengthened and harmonised for the production and use of timely, reliable, relevant data for policy uptake. Several NGOs have demonstrated the ability to undertake high-quality research using results and evidence-based approaches. However, evidence use could be strengthened by better engaging government and key stakeholders in the generation process from the design stage.

\section{Conclusions on civil society organisation engagement and evidence use}

In terms of the roles outlined in Table 1, the cases show examples of representation, advocacy and specific technical inputs being provided. We also see building capacity of CSOs (by other CSOs) to participate in all the cases. Some of the CSOs are directly involved in service delivery (e.g. around victim empowerment in the VAWC case, agricultural services with PNOPPA in Benin), whilst others are supporting other CSOs to participate in policy processes effectively.

We also see the implications of levels of participation and types of relationships. We see how manipulation of CSOs led to a breakdown of trust in Kenya, and deliberate effort to include CSO voice in the evaluation in context where the relationships are difficult and often confrontational facilitated greater use of evaluation evidence by different stakeholders in South Africa case. In the latter case, a process of dialogue was necessary to overcome hostile attitudes on both sides. Where there has been a more empowering outcome, for example, with the involvement of CSOs in Benin, and later with VAWC, this has led to both strong participation of the CSOs, as well as a larger contribution to policy and practice outcomes, and a more co-operative relationship.

The case of IAA/DLT could be seen as co-operative, but also possibly co-optive. Whilst there is common interest in having a scorecard of local government performance, CDD-Ghana is doing this to strengthen CSO advocacy where services are poor whilst government, particularly at national level, has differing goals, for example, possibly to shift the blame for poor performance to poorly resourced local government.

The cases demonstrate the value and importance of CSO engagement in evidence-informed development policy and practice notably because of the reliance of governments on CSOs for service delivery as well as the contributions of CSOs towards evidence use through strengthening demand for evidence as well as generating and supporting use processes (as we saw in the case of CDD-Ghana).

The cases equally demonstrate the significance of evidenceinformed engagement processes, in light of the reality that policy (making and implementing) is a political process involving multiple actors each with their own agendas and 
interests. Linked to this are lessons around the importance of establishing systems and processes to institutionalise evidence use as well, what Parkhurst (2017) refers to as 'good governance of evidence'. This included ensuring that trusted relationships were developed between the different stakeholder groups, mitigating against factors that could negatively affect perceived legitimacy (e.g. the concerns around elite capture in the Kenya case) and creating spaces where meaningful dialogue is possible. This requires skills that must go beyond those directly linked to generating high-quality evidence, such as facilitation and knowledge brokering.

We also see that the role of CSOs is facilitated in many cases by DPs, and that without this support they would struggle to play a major role, except in South Africa where many NGO services are funded by government, although erratically. This has positive aspects but also concerns, as different DPs with different agendas pick different CSOs to support.

\section{Acknowledgements}

\section{Competing interests}

The authors declare that they have no financial or personal relationships that may have inappropriately influenced them in writing this article.

\section{Authors' contributions}

M.P. is the lead author and co-editor of the book from which the cases are drawn, case on civil society engagement in Wildlife Conservation and Management Act, Kenya. M.A. is the co-author and contributed towards the cases on violence against women and children. E.D.-G. is the co-author and included cases on agricultural policy in Benin. D.B.-A. is the co-author and was responsible for cases on sanitation in Ghana. I.G. is the author and co-editor of the book from which the cases are drawn.

\section{Ethical considerations}

This article followed all ethical standards for research without direct contact with human or animal subjects.

\section{Funding infromation}

This research was funded by the Hewlett Foundation and closely linked to the work of the Twende Mbele partnership supporting African governments to undertake effective Monitoring and Evaluation (M\&E).

\section{Data availability statement}

Data sharing is not applicable to this article as no new data were created or analysed in this study.

\section{Disclaimer}

The views and opinions expressed in this article are those of the authors and do not necessarily reflect the official policy or position of any affiliated agency of the authors.

\section{References}

Arnstein, S.R., 1969, 'A ladder of citizen participation', Journal of the American Institute of Planners35(4),216-224.https://doi.org/10.1080/01944366908977225

Barberton, C., Ragwala, L., Budlender, D. \& Mohamed, Z., 2018, 'Performance and expenditure review: Cost implications of funding for NPOs following the Nawongo court judgements', Government Technical Advisory Centre, National Treasury, Cornerstone Economic Research, viewed 19 November 2020, from https://www. gtac.gov.za/perdetail/Cost\%20implications\%20 of 20funding\%20NPOs\%20 following\%20the\%20NAWONGO\%20court\%20judgements.pdf.

Cairney, P., 2016, The politics of evidence-based policy making, Palgrave Macmillan, London.

Centre for Democratic Development Ghana, 2017, 'Ghana's district league table report 2017', I am aware Ghana, viewed 11 June 2018, from http:// iamawareghana.com/assets/uploads/DLT\%20Documents/DLT\%2017/DLT\%20 REPORT\%20FINAL\%202017\%20(Website).compressed.pdf.

Court, J., Mendizabal, E., Osborne, D. \& Young, J., 2006, 'Policy engagement: How civil society can be more effective', Overseas Development Institute, viewed 15 December 2019, from https://www.odi.org/sites/odi.org.uk/files/odi-assets/ publications-opinionfiles/200.pdf.

Department of Planning, Monitoring and Evaluation (DPME) \& Department of Social Development (DSD), 2016, 'The diagnostic review of the state response to violence against women and children', Department of Planning, Monitoring and Evaluation and Department of Social Development, Pretoria.

Department of Planning, Monitoring and Evaluation (DPME) \& Department of Social Development (DSD), 2017, 'The evaluation of the non-profit regulatory system', Report, Department of Planning, Monitoring and Evaluation and Department of Social Development, Pretoria.

Edwards, M., 2011, 'Introduction: Civil society and the geometry of human relations', in M. Edwards (ed.), The Oxford handbook of civil society, 1st edn., Oxford University Press, Oxford.

Goldman, I. \& Pabari, M. (eds.), 2020, Using evidence for policy and practice: Lessons from Africa, Routledge, Taylor \& Francis Group, New York, NY.

Gould, C., 2018, 'Glimmers of light: Opportunities for preventing violence in South Africa', Wilson Centre, viewed 22 November 2019, from https://www.wilsoncenter. org/publication/glimmers-light-opportunities-for-preventing-violence-south-africa.

Gould, C., Mufamadi, D., Hsiao, C. \& Amisi, M., 2017, 'Reducing violence in South Africa: From policing to prevention', vol. 106, Institute for Security Studies, viewed 22 Novemver 2019, from https://issafrica.s3.amazonaws.com/site/uploads/ policybrief106.pdf.

Green, D., 2019, 'Closing civic space: Trends, drivers and what donors can do about it' From poverty to power, viewed 14 January 2020, from https://oxfamblogs.org/ $\mathrm{fp} 2 \mathrm{p} /$ closing-civic-space-trends-drivers-and-what-donors-can-do-about-it/.

Jones, E., Amidu, I.-T., Sefa-Nyarko, C., Mustapha, H. \& PDA Team, 2019, Formative evaluation of the 'I Am Aware' social accountability project in Ghana, Oxford Policy Management Limited, Oxford.

Kameri-Mbote, P., 2000, 'The operational environment and constraints for NGOs in Kenya: Strategies for good policy and practice', International Environmental Law Research Centre (IELRC), viewed 27 November 2019, from https://www.ielrc.org/ content/w0002.pdf.

Kawulich, B.B., 2005, 'Participant observation as a data collection method [81 paragraphs]', Forum Qualitative Sozialforschung / Forum: Qualitative Socia Research 6(2). https://nbn-resolving.de/urn:nbn:de:0114-fqs0502430

Keter, S.M., 2014, 'A report of CSO dialogues in Kenya', Poverty Eradication Network $(P E N)$, viewed 27 November 2019, from https://penkenya.org/upgrade/ wordpress/wp-content/uploads/2018/06/csos-leaders-dialogue-report2015.pdf.

Kode, D., 2018, 'Civic space restrictions in Africa', African Centre for the Constructive Resolution of Disputes, viewed 11 November 2019, from https://www.accord.org. $\mathrm{za} /$ conflict-trends/civic-space-restrictions-in-africa/.

Langer, L., Goldman, I. \& Pabari, M., 2020, Analytical framework used to guide case study research. In Using evidence for policy and practice - Lessons from Africa, Routledge, Taylor \& Francis Group, New York, NY.

Langer, L., Tripney, J., Gough, D., 2016, The science of using science: Researching the use of research evidence in decision-making, Technical Report, Evidence for Policy and Practice Information and Co-ordinating Centre, UCL Institute of Education, London.

Mo Ibrahim Foundation, 2018, 2018 Ibrahim index of African governance: Index report, Mo Ibrahim Foundation, viewed 14 November 2020, from https://www. tralac.org/documents/resources/africa/2363-2018-ibrahim-index-of-africangovernance-index-report/file.html.

Mongbo, R. \& Aguemon, D., 2015, Action publique, acteurs, ressources et pouvoir: cas de la relecture du Plan Stratégique de Relance du Secteur Agricole au Bénin, Communication au Colloque 2015 de l'APAD, Kuala Lumpur, 17-18th November.

MDR, 2000, Déclaration de Politique de Développement Rural, Ministère du Développement Rural, Bénin.

MPD, 2016, Synthèse de l'étude sur l'utilisation des résultats des évaluations réalisées au cours de la période 2010-2013, Direction Générale de l'Évaluation, Ministère du Plan et du Développement, Bénin.

Najam, A., 2000, 'The four C's of government-third sector relations', Nonprofit Management and Leadership 10(4), 375-396. 
Obadare, E. (ed.), 2014, 'The handbook of civil society in Africa', in Nonprofit and Civil Society Studies Volume 20, pp. i-490, Springer, New York, NY. https://doi. Society Studies Volume 20, pp.
org/10.1007/978-1-4614-8262-8

Organisation for Economic Cooperation and Development (OECD), 2019, Aid for civil society organisations: Statistics based on DAC Members' reporting to the creditor reporting system database (CRS), 2016-2017, viewed 14 November 2019, from http://www.oecd.org/dac/financing-sustainable-development/developmentfinance-topics/Aid-for-CSOs-2019.pdf.

Parkhurst, J.O., 2017, The politics of evidence: From evidence-based policy to the good governance of evidence, Routledge, Taylor \& Francis Group, Oxon/New York, NY.

Pollard, A., Court, J. \& Overseas Development Institute, 2005, How civil society organisations use evidence to influence policy processes: A literature review, Overseas Development Institute, London.
Public Affairs Research Institute (PARI), 2016, Confrontational, complementary, cooperative or co-opted? Social justice organisations working with the state, The Raith Foundation, Johannesburg.

Rainey, S., Wakunuma, K. \& Stahl, B., 2017, 'Civil society organisations in research: A literature-based typology', VOLUNTAS: International Journal of Voluntary and Nonprofit Organizations 28(5). https://doi.org/10.1007/s11266-016-9816-y

UN General Assembly, 2015, Transforming our world: The 2030 agenda for sustainable development, viewed 14 November 2019, from https://www.refworld.org/ docid/57b6e3e44.htm

Weyrauch, V., Echt, L. \& Suliman, S., 2016, 'Knowledge into policy: Going beyond "context matters", Politics \& Ideas, viewed 09 November 2019, from www. politicsandideas.org/wp-content/uploads/2016/07/Going-beyond-contextmatters-Framework_Pl.compressed.pdf. 